\title{
Borrelia burgdorferi Bind to Epithelial Cell Proteoglycans
}

Robin D. Isaacs

Department of Medicine, Department of Veterans Affairs Medical Center and

the University of Mississippi Medical Center, Jackson, Mississippi 39216

\begin{abstract}
Borrelia burgdorferi adhere to mammalian cells in vitro but neither the ligand(s) nor the receptor(s) has (have) been clearly established. Using an in vitro attachment-inhibition assay, a $B$. burgdorferi attachment mechanism has been identified. Heparin, heparan sulfate, and dermatan sulfate reduced the attachment of virulent $B$. burgdorferi strain 297 to HeLa cells by $\sim 60 \%$. In addition, virulent, but not avirulent, $B$. burgdorferi strains B31, N40, and HB19 demonstrated heparin attachment-inhibition. Attachment to Chinese hamster ovary cells deficient in heparan sulfate proteoglycans was reduced by $68 \%$ compared to attachment to wild-type cells and was identical to attachment at maximum heparin inhibition to the wildtype cells. Pretreatment of HeLa cell monolayers with heparitinase, heparinase, and chondroitinase $\mathrm{ABC}$, but not with chondroitinase $A C$, reduced borrelial attachment by $\sim 50 \%$. $A$ moderately high affinity, low copy number, promiscuous $B$. burgdorferi glycosaminoglycan receptor was demonstrated by equilibrium binding studies. A 39-kD polypeptide, purified by heparin affinity chromatography from Triton X-100 extracts derived from virulent borrelia, was a candidate for this receptor. These studies indicate that one mode of $B$. burgdorferi attachment to eukaryotic cells is mediated by a borrelial glycosaminoglycan receptor attaching to surface-exposed proteoglycans on mammalian cells. (J. Clin. Invest. 1994. 93:809-819.) Key words: bacterial adherence $\bullet$ Borrelia burgdorferi $\bullet$ glycosaminoglycans $\bullet$ Lyme borreliosis • proteoglycans
\end{abstract}

\section{Introduction}

Lyme borreliosis, a tick-borne infection caused by the spirochete Borrelia burgdorferi (1), is a chronic multisystem disorder with skin, central nervous system, cardiac, and joint manifestations (2). It is the most prevalent vector-borne disease in the United States of America with $\sim 8,600$ cases reported in 1989 (3). Because many cases of early Lyme borreliosis escape clinical detection and untreated infection may have debilitating long-term consequences $(2,4)$, there has been a concerted research effort to understand the pathogenesis of this disease.

These data were presented in part in abstract form at the Southern Regional Meeting of the American Federation for Clinical Research, New Orleans, LA, 21-23 January 1993 and at the 93rd General Meeting of the American Society for Microbiology, Atlanta, GA 16-20 May 1993.

Address correspondence to Dr. Robin D. Isaacs, Department of Veterans Affairs Medical Center (151), 1500 East Woodrow Wilson Drive, Jackson, MS 39216.

Received for publication 17 February 1993 and in revised form 29 July 1993.

The Journal of Clinical Investigation, Inc.

Volume 93, February 1994, 809-819
Attachment of $B$. burgdorferi to host cells, as with other bacteria $(5,6)$, is thought to be a critical early step in the pathogenesis of Lyme borreliosis. In vitro, B. burgdorferi attach to a variety of endothelial and epithelial cells (7-11) and to the subendothelial cell matrix (7), but the nature of the ligand(s) or the receptor(s) is not clearly established (12). These observations combined with the multiple organ system involvement seen in clinical infection (4) suggest that at least one mode of $B$. burgdorferi attachment utilizes a host cell molecule which is distributed on the cell surface of many different cell types.

Glycosaminoglycans (GAGs) ${ }^{1}$ are linear, sulfated heteropolysaccharides that have a characteristic disaccharide repeat sequence $(13,14)$. With the exception of hyaluronic acid, GAGs are covalently linked to core proteins to form proteoglycans (PGs) $(13,14)$. As PGs are expressed on the surface of virtually all mammalian cells (15), they are potential targets for a microbial cytoadhesin. GAG-mediated microbial attachment has been suggested for a limited number of pathogenic microorganisms, including viruses (16-19), bacteria $(20,21)$, and protozoa (22-25). Two classes of GAG-mediated microbial cytoadhesion have been partially characterized: (a) Trypanosoma cruzi (25) and some members of the Herpetoviridae (17-19) express GAG receptors which bind to mammalian cell surface-exposed PGs; $(b)$ Chlamydia trachomatis employs a trimolecular mechanism for attachment in which GAGs bridge mutual GAG receptors on the host cell and on the chlamydial outer membrane surfaces (20).

This paper now reports that virulent $B$. burgdorferi bind to host cell surface-exposed GAGs. Equilibrium binding studies have identified a moderately high-affinity, low-copy number, promiscuous B. burgdorferi GAG receptor. A $39-\mathrm{kD}$ B. burgdorferi molecule isolated by heparin affinity chromatography is a candidate for this receptor.

\section{Methods}

Cell lines and bacterial strains. B. burgdorferi strains and mammalian cell lines used in these studies are listed in Table I. Borrelia were cultivated at $33^{\circ} \mathrm{C}$ in Barbour-Stoenner-Kelley (BSK) medium containing $25 \mathrm{~g}$ /liter BSA (Sigma Chemical Co., St. Louis, MO) and no gelatin (26). The spirochetes were radiolabeled intrinsically by the addition of 5-10 $\mu \mathrm{Ci}$ of Trans ${ }^{35} \mathrm{~S}$-Label ( an $\sim 70: 30$ mixture of $\left[{ }^{35} \mathrm{~S}\right]$ methionine and $\left[{ }^{35}\right.$ S ] cysteine; ICN Biomedicals, Inc., Lisle, IL) to early log-phase cultures followed by incubation at $33^{\circ} \mathrm{C}$ until the culture had a density of $\sim 10^{8}$ organisms $/ \mathrm{ml}(11) .{ }^{35} \mathrm{~S}$-labeled organisms were recovered by differential centrifugation with one wash in PBS to remove unincorporated radiolabel; in excess of $99 \%$ of the radiolabel in the final washed organisms was TCA-precipitable. Spirochetes were enumerated by darkfield microscopy. In experiments requiring virulent organ-

1. Abbreviations used in this paper: BSK, Barbour-Stoenner-Kelley; $\mathrm{CHO}$, Chinese hamster ovary; CS, chondroitin sulfate; DS, dermatan sulfate; GAG, glycosaminoglycan; HS, heparan sulfate; PG, proteoglycan. 
Table I. Mammalian Cell Lines and Bacterial Strains Used in These Studies

\begin{tabular}{|c|c|c|c|}
\hline Strain/cell line & Description* & Source & Reference \\
\hline \multicolumn{4}{|l|}{ Borrelia strains } \\
\hline \multirow[t]{2}{*}{ B. burgdorferi strain B31 } & low passage, virulent & S. Norris ${ }^{\ddagger}$ & 26 \\
\hline & high passage, avirulent & J. D. Radolf ${ }^{\S}$ & \\
\hline \multirow[t]{2}{*}{ B. burgdorferi strain 297} & low passage, virulent & J. D. Radolf & 49 \\
\hline & high passage, avirulent & J. D. Radolf & \\
\hline \multirow[t]{2}{*}{ B. burgdorferi strain N40 } & low passage, virulent & J. D. Radolf & 50 \\
\hline & high passage, avirulent & J. D. Radolf & \\
\hline \multirow[t]{2}{*}{ B. burgdorferi strain $\mathrm{HB} 19$} & low passage, virulent & J. D. Radolf & 49 \\
\hline & high passage, avirulent & J. D. Radolf & \\
\hline \multicolumn{4}{|l|}{ Mammalian cell lines } \\
\hline HeLa (ATCC CCL 2) & $\begin{array}{l}\text { epithelial-like human cell line derived from } \\
\text { carcinoma of the cervix }\end{array}$ & $\begin{array}{l}\text { ATCC, } \\
\text { Rockville, MD }\end{array}$ & \\
\hline CHO K1 (ATCC CCL 61) & $\begin{array}{l}\text { epithelial-like Chinese hamster cell line } \\
\text { derived from ovarian tissue }\end{array}$ & J. Eskoll & \\
\hline CHO pgsD-803 & $\begin{array}{l}\text { derived from CHO K1; expresses } \sim 10 \% \text { of } \\
\text { the normal amount of cell surface- } \\
\text { associated } \mathrm{HS} \text { and } \sim 50 \% \text { of the normal } \\
\text { amount of CS }\end{array}$ & J. Esko & 37,38 \\
\hline CHO pgsE-606 & $\begin{array}{l}\text { derived from } \mathrm{CHO} \mathrm{Kl} \text {; expresses normal } \\
\text { amounts of cell surface-associated HS } \\
\text { and } \mathrm{CS} \text {, but the HS is sulfated } \sim 33 \% \text { of } \\
\text { normal }\end{array}$ & J. Esko & 39,40 \\
\hline
\end{tabular}

* Key: Low passage, in vitro passages 3-10; high passage, in vitro passage > 50; virulent, infectious in mice; avirulent, reported as noninfectious in mice by source.

${ }^{\ddagger}$ S. Norris, University of Texas Health Science Center, Houston, TX.

J. D. Radolf, University of Texas Southwestern Medical Center, Dallas, TX.

"J. Esko, University of Alabama, Birmingham, AL.

isms, only borrelia from passages 4 through 10 were used; virulent $B$. burgdorferi were maintained by passage through BALB/c mice (27-29).

Mammalian cells were grown at $37^{\circ} \mathrm{C}$ in $5 \% \mathrm{CO}_{2}$. HeLa cells were routinely grown in MEM (Gibco BRL Life Technologies, Inc., Gaithersburg, MD) supplemented with $10 \%$ ( $\mathrm{vol} / \mathrm{vol})$ heat-inactivated FCS (Gibco BRL), MEM nonessential amino acids (Sigma), $100 \mathrm{U} /$ $\mathrm{ml}$ penicillin $\mathrm{G}$ (Sigma), and $0.1 \mathrm{mg} / \mathrm{ml}$ streptomycin (Sigma). Chinese hamster ovary (CHO) cells were routinely grown in Ham's F12 nutrient mixture (Gibco BRL) supplemented with $7.5 \%$ (vol/vol) heat-inactivated FCS, $100 \mathrm{U} / \mathrm{ml}$ penicillin $\mathrm{G}$, and $0.1 \mathrm{mg} / \mathrm{ml}$ streptomycin. Cells were released from tissue culture flasks by incubation in $0.25 \%$ (wt/vol) trypsin (Sigma) in PBS, and were enumerated after trypan blue staining using a hemocytometer.

Chemicals and other reagents. Heparin $(176 \mathrm{U} / \mathrm{mg})$, heparan sulfate (HS), chondroitin sulfate (CS) A, dermatan sulfate (DS), CS C, keratan sulfate, hyaluronic acid, and dextran sulfate (average $M_{\mathrm{r}} 8,000$ D) were purchased from Sigma Chemical Co. Completely desulfated, $\mathrm{N}$-acetylated heparin, completely desulfated, $\mathrm{N}$-sulfated heparin, $\mathrm{N}$ desulfated, $\mathrm{N}$-acetylated heparin, heparinase, heparitinase, chondroitinase $\mathrm{ABC}$, chondroitinase $\mathrm{AC}$, keratanase, and hyaluronidase were purchased from Seikagaku America, Inc. (Rockville, MD).

In vitro attachment assay. The in vitro attachment assay was based on those reported by Thomas et al. (11), Szczepanski et al. (7), and Ma et al. (10). Some studies were performed using HeLa cell monolayers grown in 96-well tissue culture dishes [average number of HeLa cells per well $(3.6 \pm 1.1) \times 10^{4}$ ], but the standard binding assay was performed using HeLa cell monolayers grown in 24-well tissue culture dishes [average number of HeLa cells per well $(1.7 \pm 0.9) \times 10^{5}$ ]. Briefly, intrinsically radiolabeled $B$. burgdorfer $i$ were suspended in antibiotic-free tissue culture medium and then co-incubated with confluent HeLa cell monolayers cultivated using antibiotic-free tissue cul- ture medium; in the standard assay, $5 \times 10^{7}$ borrelia were added per well of a 24-well tissue culture dish and were co-incubated with the monolayers for $4 \mathrm{~h}$ at $37^{\circ} \mathrm{C}$ (approximate $B$. burgdorferi:HeLa cell ratio, 300:1). The monolayers were washed thrice with PBS and then solubilized in $0.1 \%$ (wt/vol) SDS- $0.2 \mathrm{M} \mathrm{NaOH}$. The media-PBS washes (unattached organisms) and the solubilized monolayers (attached organisms) were subjected to scintillation counting and the proportion of attached organisms was calculated.

Assays utilizing $\mathrm{CHO}$ cells were performed in a manner similar to the HeLa cell-based procedure.

Attachment-inhibition assays. Attachment-inhibition studies were undertaken using the standard assay with the modification that $B$. burgdorferi were preincubated with different amounts of potential inhibitors before co-incubation with the monolayer. The degree of attachment-inhibition at any given concentration of inhibitor was calculated as $\left(B_{\max }-B_{\text {inh }}\right) / B_{\max }$, where $B_{\max }$ was the binding in the absence of inhibitor and $B_{\text {inh }}$ was the binding in the presence of inhibitor.

Attachment assay using glutaraldehyde-fixed monolayers. In some attachment and attachment-inhibition assays the HeLa cell monolayer was pretreated with glutaraldehyde to prevent intracellular invasion by the borrelia (30). Briefly, the confluent monolayers were washed twice with PBS, incubated with $2 \%$ ( vol/vol) glutaraldehyde (Tousimis Research Corp., Rockville, MD) in PBS for 5 min at $4^{\circ} \mathrm{C}$, washed thrice with PBS, then incubated with $0.16 \mathrm{M}$ ethanolamine, $\mathrm{pH} 8.3$ (Sigma), overnight at $4^{\circ} \mathrm{C}$ to block free amino groups. Before co-incubation with intrinsically radiolabeled $B$. burgdorferi, the monolayers were washed thrice with PBS, washed twice with antibiotic-free HeLa medium, then incubated with antibiotic-free $\mathrm{HeLa}$ medium for $60 \mathrm{~min}$ at $37^{\circ} \mathrm{C}$.

Equilibrium binding studies. Equilibrium binding studies were performed in a similar manner to that described by Mukhopadhyay et al. (23) and Liang et al. (31) to identify GAG binding ligands in Leishmania donovani and Staphylococcus aureus, respectively. $\left[{ }^{3} \mathrm{H}(\mathrm{G})\right]-$ 
sodium heparin ( $0.44 \mathrm{mCi} / \mathrm{mg}$; Du Pont New England Nuclear Research Products, Boston, MA) was used as the radioligand. B. burgdorferi, recovered by differential centrifugation followed by a single wash in PBS, were suspended in antibiotic-free HeLa medium at a concentration of $5 \times 10^{8}$ organisms $/ \mathrm{ml}$. In a standard experiment, duplicate or triplicate data points were analyzed. Borrelia $\left(5 \times 10^{7}\right)$ were incubated with various concentrations of $\left[{ }^{3} \mathrm{H}\right]$ heparin in the absence (total bound heparin) or presence (nonspecifically bound heparin) of excess unlabeled heparin $(500 \mu \mathrm{g} / \mathrm{ml})$ for $60 \mathrm{~min}$, and were recovered by differential centrifugation; the reaction volume was $200 \mu \mathrm{l}$. The pellets were solubilized in SDS- $\mathrm{NaOH}$ and attached counts determined by scintillation counting. Specifically bound heparin was calculated as the difference between total and nonspecifically bound counts. Data was analyzed by Scatchard analysis $(32,33)$. The $\left[{ }^{3} \mathrm{H}\right]$ heparin used in these studies was a heterogenous mixture of molecules with $M_{\mathrm{r}} 5,000$ $20,000 \mathrm{D}$, and for the purpose of analysis, an average $M_{\mathrm{r}}$ of $10,000 \mathrm{D}$ was used.

Competitive equilibrium binding studies. Competitive equilibrium binding studies were performed in a manner similar to equilibrium binding studies with the exception that the borrelia were incubated with $100 \mathrm{ng}$ of $\left[{ }^{3} \mathrm{H}\right]$ heparin in the presence of varying concentrations of the potential competitive inhibitor.

GAG lyase pretreatment of HeLa cell monolayers. GAG lyases are enzymes which digest specific GAGs (13). They were reconstituted in PBS-50 $\mu \mathrm{M}$ calcium acetate containing $1 \mu \mathrm{g} / \mathrm{ml}$ (wt/vol) leupeptin (Calbiochem Corp., San Diego, CA) and $1 \mathrm{mM}$ benzamidine (Calbiochem). The concentration of each lyase is reported in conventional units; 1 conventional unit is $0.006 \mathrm{IU}$ ( 16). Briefly, the confluent HeLa cell monolayers were washed thrice with ice-cold PBS, then incubated with GAG lyases $4 \mathrm{U} / \mathrm{ml}$ in PBS-50 $\mu \mathrm{M}$ calcium acetate for $60 \mathrm{~min}$ at $37^{\circ} \mathrm{C}$. The GAG lyase was removed by washing thrice with ice-cold PBS, then the radiolabeled $B$. burgdorfer $i$ were added and co-incubated with the monolayers for $120 \mathrm{~min}$ at $37^{\circ} \mathrm{C}$. The proportion of attached counts was determined as for the standard assay.

Purification of $B$. burgdorferi heparin binding ligands. B. burgdorferi heparin binding molecules were purified by heparin affinity chromatography using heparin agarose (Sigma) as the affinity matrix. $B$. burgdorferi, recovered and washed once in PBS by differential centrifugation, were incubated in PBS-0.02\% (vol/vol) Triton X-100 (Sigma) at a concentration of $1 \times 10^{9} / \mathrm{ml}$. The detergent-insoluble material was removed by differential centrifugation and the detergent extract was incubated with heparin agarose ( $5 \mathrm{ml}$ extract $/ \mathrm{ml}$ of matrix) overnight at $4^{\circ} \mathrm{C}$. Attached proteins were eluted sequentially by 10 bed volumes respectively of $0.25 \mathrm{M} \mathrm{NaCl}-0.01 \%$ Triton X-100, $0.25 \mathrm{M} \mathrm{NaCl}-0.5 \%$ Triton X-100, $0.5 \mathrm{M} \mathrm{NaCl}-0.5 \%$ Triton X-100, $1 \mathrm{M} \mathrm{NaCl}-0.5 \%$ Triton $\mathrm{X}-100,2 \mathrm{M} \mathrm{NaCl}-0.5 \%$ Triton X-100, and $6 \mathrm{M}$ urea in PBS. Eluted samples were dialyzed against PBS before SDS-PAGE analysis. The 6 $M$ urea eluant was made to $0.05 \%$ Triton X-100 before dialysis to prevent hydrophobic proteins aggregating and precipitating during dialysis.

SDS-PAGE, immunoblotting, and immunologic reagents. SDSPAGE and Western blotting procedures were performed as described previously $(34,35)$. mAb $8 \mathrm{H} 3-33\left(\mathrm{IgG}_{3}\right)$ directed against the $B$. burgdorferi $41-\mathrm{kD}$ flagellar protein was provided by Michael V. Norgard, University of Texas Southwestern Medical Center. A mAb and monospecific polyclonal rabbit antiserum directed against the $B$. burgdorferi P39 antigen (36) were provided by Tom G. Schwan, NIAID Rocky Mountain Laboratories. In immunoblotting studies, mAb clone supernatants were used undiluted and the rabbit antiserum was used at a dilution of 1:500; bound antibody was detected using biotin conjugates of rabbit anti-mouse IgG or goat anti-rabbit IgG, respectively, followed by incubation with streptavidin conjugated to alkaline phosphatase (Zymed Laboratories Inc., South San Francisco, CA).

\section{Results}

B. burgdorferi attach to epithelial cells in vitro. Binding studies using HeLa cells in 96-well plates demonstrated that virulent
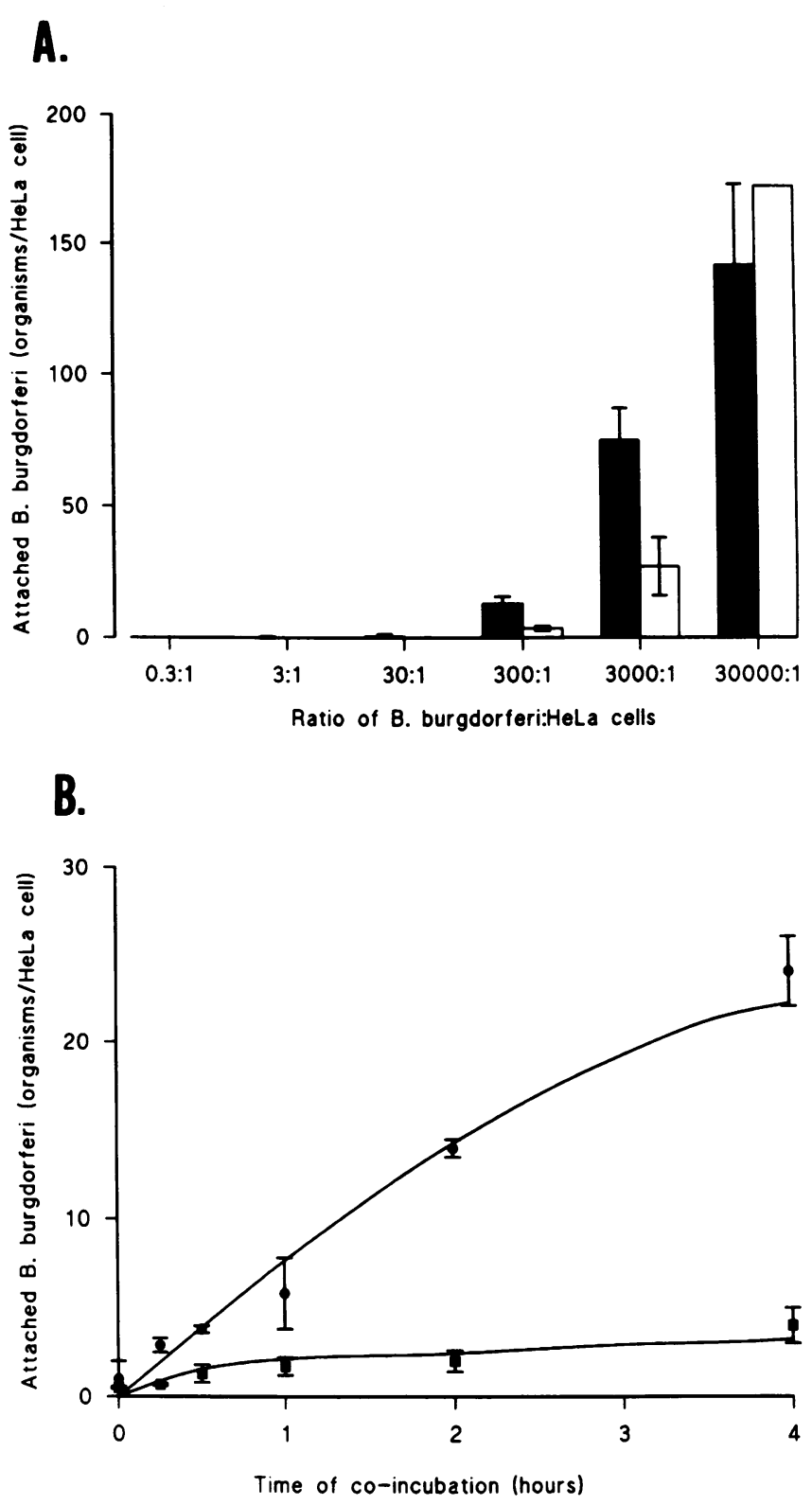

Figure 1. Characteristics of in vitro binding assay. Studies were performed using virulent $B$. burgdorferi strain 297 as described in the text. Each data point represents the mean \pm SD for three replicates. $(A)$ Virulent $B$. burgdorferi bind to unfixed $(\bullet)$ and glutaraldehydefixed ( $\square$ ) HeLa cells in a dose-dependent manner. ( $B$ ) Virulent $B$. burgdorferi attachment to HeLa cells is time- and temperature-dependent. Studies were performed at $4^{\circ} \mathrm{C}(\bullet)$ and $37^{\circ} \mathrm{C}(\bullet)$.

B. burgdorferi 297 attached to unfixed and glutaraldehydefixed HeLa cells in a dose-dependent fashion (Fig. $1 A$ ). Binding studies using HeLa cells in 24-well plates demonstrated that this attachment occurred in a time- and temperature-dependent fashion (Fig. $1 B$ ). No binding was detected when virulent $B$. burgdorferi were incubated in tissue-culture wells which had been incubated with HeLa medium without antibiotics in the absence of HeLa cells. The parameters chosen for the standard assay, $5 \times 10^{7} \mathrm{~B}$. burgdorferi co-incubated with the HeLa cell monolayer in 24-well dishes for $4 \mathrm{~h}$ at $37^{\circ} \mathrm{C}$, provided a reproducible procedure; $19 \pm 6 \%$ ( $56 \pm 18$ borrelia / HeLa cell $)$ of virulent $B$. burgdorferi strain 297 were attached/invasive after $4 \mathrm{~h}$ 
of co-incubation. Data points were performed in triplicate and in general, the standard deviation was $<10 \%$ among replicates.

$B$. burgdorferi attachment to epithelial cell monolayers is inhibited by GAGs. Initially, in vitro attachment-inhibition assays were performed with HeLa cells using purified GAGs. Weight per volume instead of molar dilutions of each GAG were utilized as each individual GAG is a heterogeneous population of polymeric molecules with varying molecular masses. Heparin, HS, and DS diminished attachment of virulent $B$. burgdorferi 297 to HeLa cell monolayers in a dose-dependent manner (Fig. 2); heparin was the most potent inhibitor (Table II). Each GAG decreased borrelial attachment by a maximum of $\sim 60 \%$ (Table II). CS A, CS C, keratan sulfate, and hyaluronic acid did not affect borrelial attachment (Table II). In addition, heparin inhibited attachment to glutaraldehyde-fixed HeLa cell monolayers in a similar manner to attachment-inhibition with unfixed monolayers (Table II, Fig. 3). In excess of $95 \%$ of spirochetes were motile after $4 \mathrm{~h}$ of incubation in antibiotic-free HeLa medium containing $10 \mu \mathrm{g} / \mathrm{ml}$ heparin.

BSK medium contains a high concentration of BSA. Two experiments established that inhibition of attachment by heparin was not a consequence of removal of BSA bound to the borrelia by the PBS wash. First, virulent B. burgdorferi 297 were washed in BSK medium by differential centrifugation before co-incubation with the heparin; heparin reduced attachment by $44 \pm 8 \%$ with an ID $_{50}$ of $0.25 \pm 0.07 \mu \mathrm{g} / \mathrm{ml}$ (dose causing $50 \%$ maximum inhibition of binding). Second, heparin attachment-inhibition studies were undertaken utilizing HeLa medium without antibiotics supplemented with $25 \mathrm{~g} /$ liter BSA; heparin reduced attachment by $40 \pm 4 \%$ with an $\mathrm{ID}_{50}$ of $0.4 \pm 0.2$ $\mu \mathrm{g} / \mathrm{ml}$. In both cases, the reduction in attachment and the $\mathrm{ID}_{50}$ were similar to studies undertaken with the standard assay ( Table II).

Charge of the GAG is an important factor in inhibition of borrelial attachment. Because interactions of GAGs with their ligands is mediated, at least in part, by ionic interactions (14), the role of the charge of GAGs in inhibiting borrelial attachment to HeLa cells was assessed. Attachment-inhibition studies were performed using dextran sulfate (average $M_{\mathrm{r}} 8,000 \mathrm{D}$ ), a polyanionic synthetic carbohydrate with similar charge den-

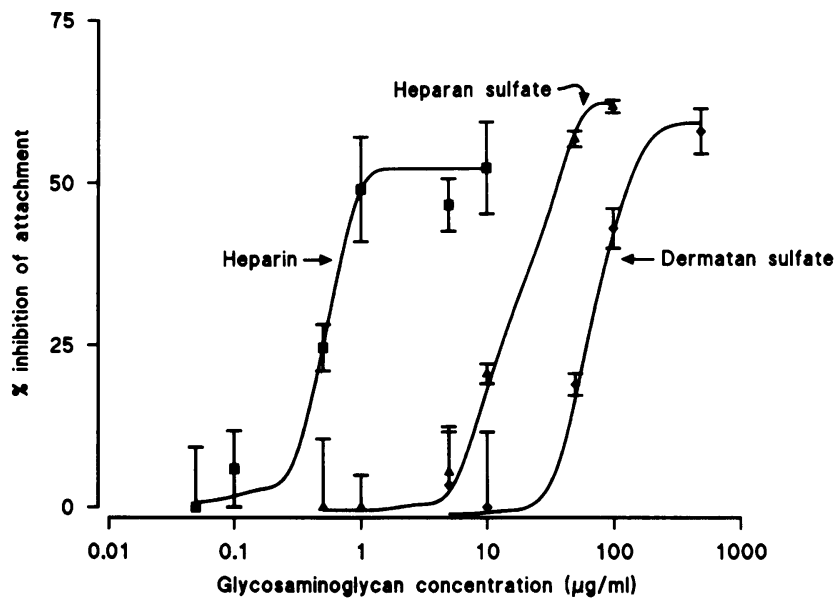

Figure 2. In vitro inhibition by GAGs of virulent $B$. burgdorferi strain 297 attachment to HeLa cells. Studies were performed as described in the text. Representative curves for heparin ( $\bullet$ ), HS ( $\triangle$ ), and DS $(\diamond)$. Each data point represents the mean \pm SD for three replicates.
Table II. In Vitro Inhibition of Binding of B. burgdorferi 297 to HeLa Cell Monolayers*

\begin{tabular}{lcc}
\hline \multicolumn{1}{c}{ GAG } & $\begin{array}{c}\text { Maximum } \\
\text { inhibition }^{\ddagger}\end{array}$ & $\mathrm{ID}_{\mathbf{s 0}}{ }^{8}$ \\
\hline Heparin, untreated monolayer & $\%$ & $\mu \mathrm{g} / \mathrm{ml}$ \\
Heparin, glutaraldehyde-treated monolayer & $53 \pm 8$ & $0.3 \pm 0.1$ \\
Heparin, completely desulfated, N-acetylated & $03 \pm 8$ & $0.3 \pm 0.3$ \\
Heparin, completely desulfated, N-sulfated & 0 & - \\
Heparin, N-desulfated, N-acetylated & 0 & - \\
Dextran sulfate (average $\left.M_{\mathrm{r}} 8,000 \mathrm{D}\right)$ & $64 \pm 1$ & - \\
HS & $67 \pm 12$ & $12 \pm 5$ \\
DS & $57 \pm 6$ & $63 \pm 0$ \\
CS A & 0 & - \\
CS C & 0 & - \\
Keratan sulfate & 0 & - \\
Hyaluronic acid & 0 & - \\
& & \\
\hline
\end{tabular}

* Results for maximum inhibition and for $\mathrm{ID}_{50}$ are the average obtained from a minimum of two experiments for each GAG.

${ }^{\ddagger}$ Difference between maximum and minimum binding as a fraction of maximum binding.

$\S$ Inhibitory dose of GAG causing $50 \%$ maximum inhibition of binding.

sity and molecular mass to heparin, and three chemically modified heparins which have differing degrees of sulfation as compared with native heparin (Table III). Dextran sulfate decreased borrelial attachment to HeLa cells to the same extent as heparin with a similar potency (Table II). Completely desulfated, $\mathrm{N}$-acetylated heparin, completely desulfated, $\mathrm{N}$-sulfated heparin, and $\mathrm{N}$-desulfated, $\mathrm{N}$-acetylated heparin did not affect attachment (Table II).

Virulent $B$. burgdorferi attachment to $\mathrm{CHO}$ cells deficient in HS PGs is reduced. Attachment of virulent B. burgdorferi 297 to two mutant $\mathrm{CHO}$ cell lines deficient in HS PGs was com-

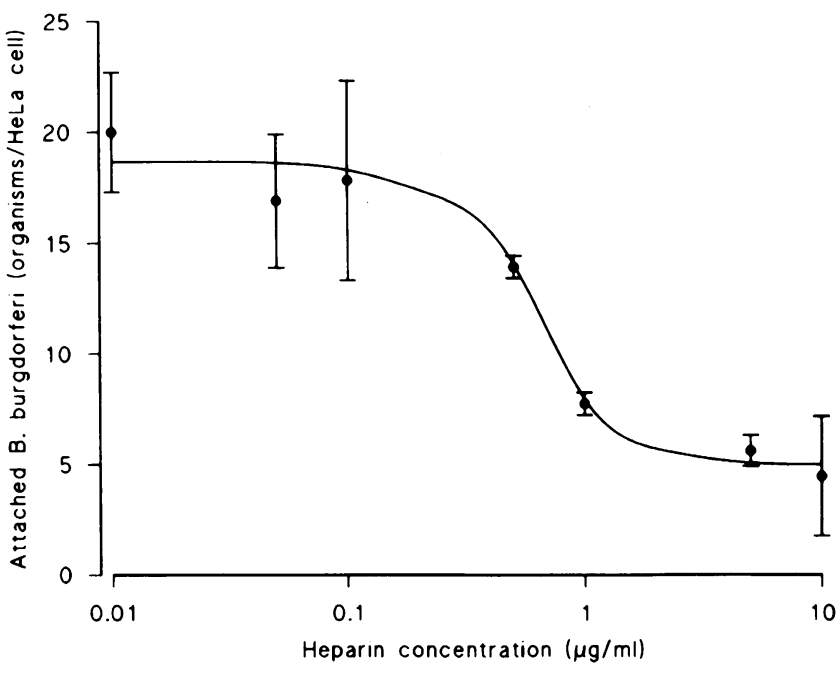

Figure 3. In vitro inhibition by heparin of virulent $B$. burgdorferi strain 297 attachment to glutaraldehyde-fixed HeLa cell monolayers. Studies were performed as described in the text. Each data point represents the mean $\pm \mathrm{SD}$ for three replicates. 
Table III. Sulfur Composition of GAGs and Chemically Modified Heparins*

\begin{tabular}{lcc}
\hline & $\begin{array}{c}\text { Percent } \\
\text { N-linked } \\
\text { sulfur }\end{array}$ & $\begin{array}{c}\text { Percent } \\
\text { total } \\
\text { sulfur }\end{array}$ \\
\hline Heparin & & 13.10 \\
Completely desulfated, N-acetylated heparin & $<0.1$ & $<1.5$ \\
Completely desulfated, N-sulfated heparin & $>4.5$ & $4.5-7.0$ \\
N-desulfated, N-acetylated heparin & $<0.2$ & $>8.0$ \\
HS & & $5.0-6.0$ \\
CS & & $6.2-6.6$ \\
DS & & $6.2-6.9$ \\
Keratan sulfate & & $7-8$ \\
Hyaluronic acid & & 0 \\
& & \\
\hline
\end{tabular}

* From manufacturer's chemical data information (Seikagaku America Inc., Rockville, MD).

pared with attachment to wild-type $\mathrm{CHO} \mathrm{K} 1$ cells. $\mathrm{CHO}$ pgsD803 expresses $10 \%$ of the normal amount of $\operatorname{HS} \operatorname{PG}(37,38)$. CHO pgsE-606 has normal quantities of HS, but the HS is sulfated $\sim 33 \%$ of normal $(39,40)$ (Table IV); inasmuch as the charge of the GAG is important in the attachment-inhibition process, this cell line has an effective partial HS PG deficiency. In order to minimize experimental variation due to enumeration and to variable growth of both the $\mathrm{CHO}$ cell lines and the borrelia, each experiment was performed on the same day using the same heparin and borrelial dilutions; parallel 24-well plates were prepared for each $\mathrm{CHO}$ cell line enabling the number of $\mathrm{CHO}$ cells per well to be determined so that the results could be expressed as borrelia attached per $\mathrm{CHO}$ cell.

In the absence of heparin, virulent $B$. burgdorferi 297 attached to the three $\mathrm{CHO}$ cell lines, $\mathrm{K} 1$, pgsD-803, and pgsE606 ( Table IV), but attachment to CHO pgsD-803 was markedly reduced as compared with attachment to CHO K1 (Fig. 4, Table IV); attachment to CHO pgsE-606 was intermediate between that to $\mathrm{CHO} \mathrm{K} 1$ and to $\mathrm{CHO}$ pgsD-803 (Table IV). Heparin diminished attachment to $\mathrm{CHO} \mathrm{K} 1$ and to $\mathrm{CHO}$ pgsE-606 in a dose-dependent manner with a similar $\mathrm{ID}_{50}$ for the two cell lines (Table IV). Heparin, however, does not affect

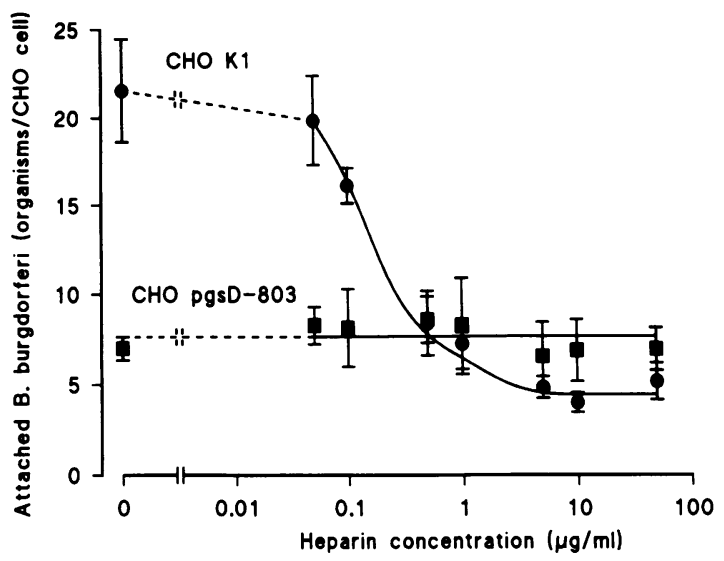

Figure 4. In vitro heparin inhibition of virulent $B$. burgdorferi strain 297 attachment to CHO K1 (•) and CHO pgsD-803 ( $)$ cells. Studies were performed as described in the text. Each data point represents the mean \pm SD for three replicates.

borrelial attachment to $\mathrm{CHO}$ pgsD-803 (Fig. 4, Table IV). The number of borrelia per $\mathrm{CHO}$ cell at maximum heparin inhibition was similar for all three cell types and was the same as attachment to $\mathrm{CHO}$ pgsD-803 in the absence of heparin (Fig. 4, Table IV).

Pretreatment of HeLa cell monolayers with GAG lyases. To investigate further the role of host cell, surface-exposed GAGs, attachment studies were undertaken using HeLa cell monolayers pretreated with GAG lyases to remove surface-exposed GAGs. Heparitinase, keratanase, and hyaluronidase specifcally cleave HS, keratan sulfate, and hyaluronic acid, respectively. Heparinase cleaves both heparin and HS because HS contains heparin-like disaccharides which are susceptible to heparinase digestion (41). Chondroitinase $\mathrm{ABC}$ cleaves CS A, $B$, and $C$, whereas chondroitinase $A C$ cleaves $C S A$ and $C$ but not CS B (dermatan sulfate). As compared with control binding, virulent $B$. burgdorferi 297 attachment was decreased by heparinase, by heparitinase, or by chondroitinase $A B C$, but was not affected by chondroitinase AC, by keratanase, nor by hyaluronidase (Table V). Heparinase in combination either with heparitinase or with chondroitinase $A B C$ produced no greater reduction in binding than heparinase alone (Table V).

Table IV. Heparin Inhibition of Attachment of Virulent B. burgdorferi 297 to CHO Cell Lines*

\begin{tabular}{|c|c|c|c|c|c|}
\hline \multirow[b]{2}{*}{ Cell line } & \multirow[b]{2}{*}{ Description } & \multirow[b]{2}{*}{$\begin{array}{l}\text { Maximum } \\
\text { inhibition }^{\ddagger}\end{array}$} & \multirow[b]{2}{*}{$\mathrm{ID}_{50}^{8}$} & \multicolumn{2}{|c|}{ Spirochetes attached per $\mathrm{CHO}$ cell" } \\
\hline & & & & Control & $\begin{array}{c}\text { At maximum } \\
\text { heparin inhibition }\end{array}$ \\
\hline & & $\%$ & $\mu g / m l$ & & \\
\hline $\mathrm{CHO} \mathrm{K} 1$ & parental & $77 \pm 1$ & $0.4 \pm 0.1$ & $22 \pm 1$ & $5 \pm 1$ \\
\hline CHO pgsD-803 & $10 \%$ normal HS & 0 & - & $6 \pm 2$ & $6 \pm 2$ \\
\hline CHO pgsE-606 & $\begin{array}{l}100 \% \text { HS, but } \\
\text { only } 33 \% \text { sulfated }\end{array}$ & $59 \pm 7$ & $0.7 \pm 0.1$ & $9 \pm 1$ & $4 \pm 1$ \\
\hline
\end{tabular}

\footnotetext{
* Results for maximum inhibition and for $\mathrm{ID}_{50}$ are the average obtained from a minimum of two experiments for each $\mathrm{CHO}$ cell line.

₹ Difference between maximum and minimum binding as a fraction of maximum binding.

${ }^{8}$ Inhibitory dose of heparin causing $50 \%$ maximum inhibition of binding.

"The average number of cells per well for each $\mathrm{CHO}$ cell line was calculated from a parallel 24-well plate produced at the same time as the plate used in the adherence studies.
} 
Table V. Effect of GAG Lyase Pretreatment of HeLa Cell Monolayers on Virulent B. burgdorferi Strain 297 Attachment

\begin{tabular}{lc}
\hline \multicolumn{1}{c}{ GAG lyase } & $\begin{array}{c}\text { Percent reduction } \\
\text { in attachment* }\end{array}$ \\
\hline Heparinase $4 \mathrm{U} / \mathrm{ml}$ & $46 \pm 6$ \\
Heparitinase $4 \mathrm{U} / \mathrm{ml}$ & $43 \pm 11$ \\
Chondroitinase ABC $4 \mathrm{U} / \mathrm{ml}$ & $46 \pm 9$ \\
Chondroitinase AC $4 \mathrm{U} / \mathrm{ml}$ & 0 \\
Keratanase $4 \mathrm{U} / \mathrm{ml}$ & 0 \\
Hyaluronidase $4 \mathrm{U} / \mathrm{ml}$ & 0 \\
Heparinase $4 \mathrm{U} / \mathrm{ml}+$ heparitinase $4 \mathrm{U} / \mathrm{ml}$ & $51 \pm 10$ \\
Heparinase $4 \mathrm{U} / \mathrm{ml}+$ chondroitinase $\mathrm{ABC} 4 \mathrm{U} / \mathrm{ml}$ & $62 \pm 18$ \\
& \\
\hline
\end{tabular}

* Difference between control binding and binding after GAG lyase treatment as a fraction of control binding.

Virulent $B$. burgdorferi have a moderately high-affinity promiscuous GAG receptor. Equilibrium binding studies, using $\left[{ }^{3} \mathrm{H}\right]$ heparin as the radioligand, were undertaken with intact virulent $B$. burgdorferi 297 and demonstrated saturable, specific heparin binding by the intact organism (Fig. 5, inset). Scatchard analysis (Fig. 5) indicated that $B$. burgdorferi possessed a GAG receptor of moderately high affinity (apparent $K_{\mathrm{d}}=56 \pm 12 \mathrm{nM}$; three experiments) and relatively low copy number $\left(\left(12 \pm 7 \times 10^{3} /\right.\right.$ organism; three experiments $)$. The possibility of a second, lower-affinity receptor was considered, but iterative modeling (32) of the data collected from three equilibrium binding studies favored the existence of only a single receptor (data not shown).

In order to determine if there was a single promiscuous GAG receptor or individual receptors for heparin, HS or DS, equilibrium binding competition studies were performed in the presence of a fixed amount of radioligand and varying amounts of each competitor. Heparin competitively inhibited $\left[{ }^{3} \mathrm{H}\right]-$ heparin binding to intact virulent B. burgdorferi 297 (Fig. 6). Dextran sulfate, HS and DS also competitively inhibited $\left[{ }^{3} \mathrm{H}\right]-$ heparin binding (data not shown), but only heparin and dextran sulfate completely displaced all bound radioligand. HS and DS, at a concentration of $100 \mu \mathrm{g} / \mathrm{ml}$, displaced only $46 \%$ and $59 \%$, respectively, of the radioligand. These results are consistent with a promiscuous GAG receptor with different affinities for heparin, HS, and DS.

Avirulent B. burgdorferi strains B31, HB19, and N40 do not exhibit heparin-inhibitable attachment. The role of GAG-mediated cytoadhesion in virulence was assessed for virulent and avirulent organisms of B. burgdorferi strains 297, B31, HB19, and N40. Continuous in vitro cultivation attenuates $B$. burgdorferi virulence (28); all avirulent strains used were high-passage isolates and were stated to be avirulent by the laboratory supplying the strain. All virulent isolates were from in vitro passages 3 through 10.

The proportion of $B$. burgdorferi which attached to the HeLa cell monolayers varied as to the strain (Table VI). Virulent strains B31, N40, and HB19 demonstrated increased attachment as compared with their respective avirulent strain; virulent and avirulent $B$. burgdorferi 297 showed a similar degree of attachment (Table VI).

All four virulent strains tested demonstrated heparin-inhibitable attachment to HeLa cell monolayers with similar parameters (Table VI). In distinct contrast, heparin does not affect attachment of avirulent $B$. burgdorferi strains B31, HB19, and N40 to HeLa cells (Table VI); interestingly, avirulent $B$. burgdorferi 297 demonstrates heparin-inhibitable attachment (Table VI). Equilibrium binding studies were undertaken with virulent and avirulent $B$. burgdorferi $\mathrm{B} 31$; virulent B31 expressed a low copy number GAG receptor $\left((19 \pm 7) \times 10^{3} /\right.$ organism; three experiments) with apparent $K_{\mathrm{d}} 74 \pm 11 \mathrm{nM}$ (three

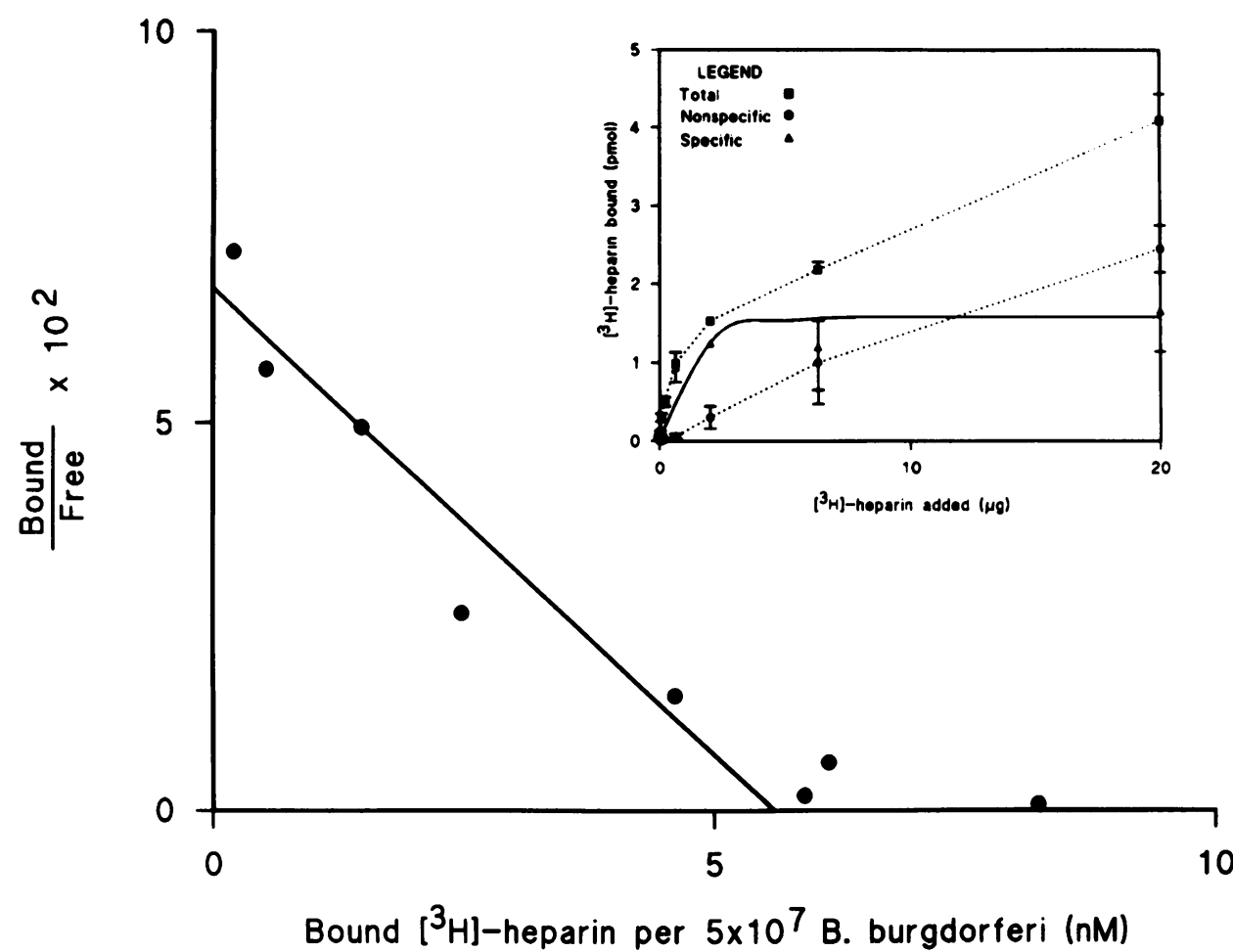

Figure 5. Scatchard analysis of heparin binding to intact virulent B. burgdorferi strain 297. Inset shows heparin binding curve; borrelia were incubated with $\left[{ }^{3} \mathrm{H}\right]-$ heparin in the presence $(\bullet)$ or in the absence ( $\square$ ) of excess unlabeled heparin and specific binding (dark line, $\Delta)$ is the difference between total and nonspecific binding. Each data point represents the mean \pm SD for two replicates. 


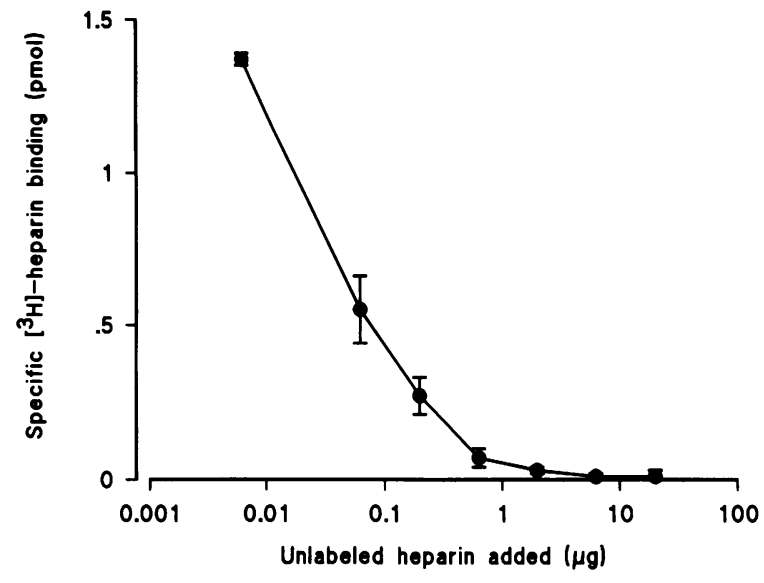

Figure 6. Binding of $\left[{ }^{3} \mathrm{H}\right]$ heparin to virulent $B$. burgdorferi strain 297 is competitively inhibited by unlabeled heparin. Studies were performed as described in the text. Each data point represents the mean $\pm \mathrm{SD}$ for two replicates.

experiments), but avirulent B31 does not express this receptor (three experiments).

Purification of $B$. burgdorferi heparin binding ligands by heparin affinity chromatography. B. burgdorferi heparin binding ligands were purified from Triton X-100 solubilized borrelial membrane proteins by heparin affinity chromatography. Although Triton X-100 solubilizes $B$. burgdorferi proteins from both the outer and the cytoplasmic membranes, the soluble detergent extract is relatively enriched for outer membrane proteins at low detergent concentrations $(35,42)$. In preliminary studies, intrinsically radiolabeled $B$. burgdorferi 297 were incubated with $0 \%, 0.01 \%$, and $0.02 \%$ Triton X-100 in PBS; $5 \%, 10 \%$, and $20 \%$ of incorporated counts were solubilized with the respective detergent concentrations, indicating that even $0.01 \%$ Triton X-100, a concentration less than Triton X-100's critical micellar concentration $(\mathrm{cmc})(\mathrm{cmc} \approx 0.02 \%)(43)$, solubilized borrelial components. On the basis of these results, $0.02 \%$ Triton X-100 extracts were used for purification of $B$. burgdorferi heparin binding ligands.
SDS-PAGE analysis of a typical purification procedure using detergent extracts derived from virulent $B$. burgdorferi 297 is shown in Fig. $7(A)$. The original detergent extract contains a number of proteins (lane $S$ ), but the majority of those which bound to the heparin matrix, including OspA and OspB, were eluted by only $0.25 \mathrm{M} \mathrm{NaCl}$ (lane 1); additionally, a lesser amount of the OspA and OspB were eluted by $0.5 \mathrm{M} \mathrm{NaCl}$ (lane 2). A small, reproducible group of proteins with $M_{\mathrm{r}}$ of $40,000,38,000$, and 24,000 D were eluted by $1 \mathrm{M} \mathrm{NaCl}$ (lane 3 ) and no additional proteins were eluted by $2 \mathrm{M} \mathrm{NaCl}$ (lane 4 ); trace amounts of OspA and OspB were present in the $1 \mathrm{M}$ $\mathrm{NaCl}$ fractions (data not shown). One protein of $M_{\mathrm{r}} 39,000 \mathrm{D}$ had such high affinity for heparin that $6 \mathrm{M}$ urea was required for its elution (lane 5). This $39-\mathrm{kD}$ protein is distinct from the proteins eluted by $1 \mathrm{M} \mathrm{NaCl}$ on the basis of $M_{\mathrm{r}}$.

The borrelial origin of these eluted proteins was confirmed unequivocally. First, the borrelial heparin binding ligands were purified from detergent extracts derived from intrinsically radiolabeled spirochetes; bands identified by autoradiography (Fig. 7 B) corresponded with those seen by silver stain (Fig. 7 $A$ ). Second, the 24-, 38-, 39-, and 40-kD proteins were not purified when only BSK medium was applied to the column indicating that they are not eukaryotic heparin binding proteins present in the rabbit sera (data not shown). Third, agarose matrix without heparin was incubated with radiolabeled detergent extract, washed extensively in PBS, and any attached molecules released by boiling in SDS-PAGE final sample buffer; no borrelial molecules were detected in the sample either when they were subjected to scintillation counting or when they were analyzed by SDS-PAGE followed by autoradiography.

Detergent extracts derived from virulent and avirulent $B$. burgdorferi B31, respectively, were subjected to heparin affinity chromatography. SDS-PAGE analysis of the fractions derived from the virulent strain was the same as that seen with virulent $B$. burgdorferi 297 (data not shown). In contrast, analysis of fractions derived from avirulent $B$. burgdorferi B31 (Fig. $7 C$ ) indicated that the $1 \mathrm{M} \mathrm{NaCl}$ (lane 3) and $6 \mathrm{M}$ urea (lane 5 ) eluants were distinct from those obtained with detergent

Table VI. Summary of Studies with Virulent and Avirulent B. burgdorferi Strains*

\begin{tabular}{|c|c|c|c|c|c|c|}
\hline \multirow[b]{2}{*}{$\begin{array}{l}\text { B. burgdorferi } \\
\text { strain }\end{array}$} & \multirow[b]{2}{*}{ Virulence } & \multicolumn{2}{|c|}{ Attachment in the absence of heparin } & \multicolumn{2}{|c|}{ Heparin attachment-inhibition } & \multirow[b]{2}{*}{$\begin{array}{l}\text { GAG } \\
\text { receptor }\end{array}$} \\
\hline & & $\begin{array}{l}\text { Percent } \\
\text { bound }^{\ddagger}\end{array}$ & $\begin{array}{l}\text { Spirochetes } \\
\text { attached per } \\
\text { HeLa cell }\end{array}$ & $\begin{array}{l}\text { Maximum } \\
\text { inhibition }^{8}\end{array}$ & $\mathrm{ID}_{\text {so }}{ }^{\prime \prime}$ & \\
\hline & & $\%$ & & $\%$ & $\mu g / m l$ & \\
\hline \multirow[t]{2}{*}{297} & V & $19 \pm 6$ & $56 \pm 18$ & $53 \pm 8$ & $0.3 \pm 0.1$ & + \\
\hline & A & $16 \pm 5$ & $47 \pm 15$ & $55 \pm 4$ & $0.35 \pm 0.02$ & ND \\
\hline \multirow[t]{2}{*}{ B31 } & V & $22 \pm 10$ & $64 \pm 29$ & $53 \pm 10$ & $0.5 \pm 0.2$ & + \\
\hline & A & $4 \pm 3$ & $12 \pm 9$ & 0 & - & - \\
\hline \multirow[t]{2}{*}{ N40 } & V & $15 \pm 5$ & $44 \pm 15$ & $46 \pm 11$ & $0.5 \pm 0.1$ & ND \\
\hline & A & $4 \pm 2$ & $12 \pm 6$ & 0 & - & ND \\
\hline \multirow[t]{2}{*}{ HB19 } & $\mathrm{V}$ & $17 \pm 6$ & $50 \pm 18$ & $54 \pm 3$ & $0.6 \pm 0.3$ & ND \\
\hline & A & $6 \pm 4$ & $18 \pm 12$ & 0 & - & ND \\
\hline
\end{tabular}

* Abbreviations used: V, virulent; A, avirulent; ND, not done; +, moderately high-affinity GAG receptor present; -, moderately high-affinity GAG receptor not present.

${ }^{\ddagger}$ Proportion of spirochetes bound in the absence of heparin after co-incubation at $37^{\circ} \mathrm{C}$ for $4 \mathrm{~h}$.

$\$$ Difference between maximum and minimum binding as a fraction of maximum binding.

"Inhibitory dose of heparin causing 50\% maximum inhibition of binding. 

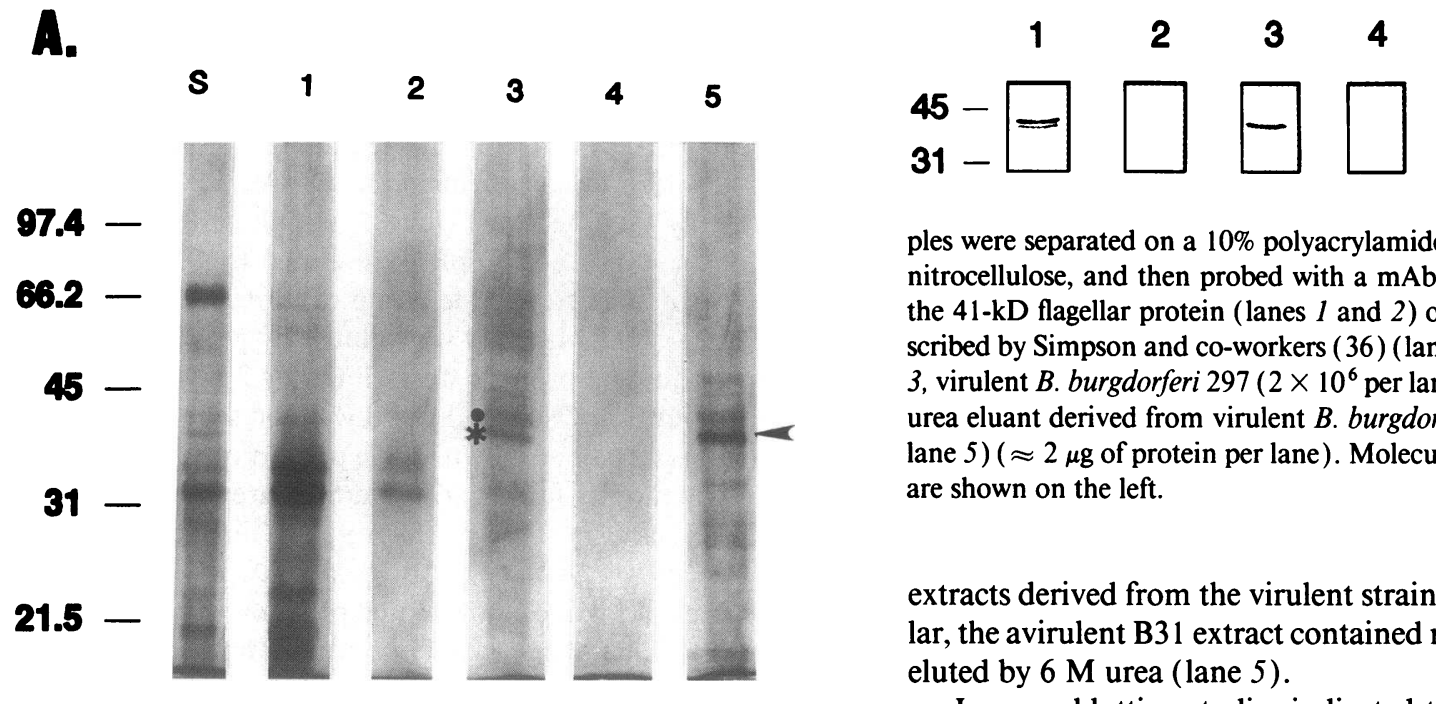

Figure 8 . The $39-\mathrm{kD} B$. burgdorferi heparin binding protein eluted by $6 \mathrm{M}$ urea is neither the $41-\mathrm{kD}$ flagellar nor the P39 antigen. Sam-

ples were separated on a $10 \%$ polyacrylamide gel, electroblotted to nitrocellulose, and then probed with a mAb directed against either the 41-kD flagellar protein (lanes 1 and 2) or the P39 antigen described by Simpson and co-workers (36) (lanes 3 and 4). Lanes 1 and 3, virulent $B$. burgdorferi $297\left(2 \times 10^{6}\right.$ per lane $)$; lanes 2 and 4, $6 \mathrm{M}$ urea eluant derived from virulent $B$. burgdorferi 297 (see Fig. 7 A, lane 5$)(\approx 2 \mu \mathrm{g}$ of protein per lane). Molecular mass markers in $\mathrm{kD}$ are shown on the left.

extracts derived from the virulent strain (Fig. $7 \mathrm{~A}$ ); in particular, the avirulent B31 extract contained no proteins which were eluted by $6 \mathrm{M}$ urea (lane 5).

Immunoblotting studies indicated that the $39-\mathrm{kD}$ protein eluted by $6 \mathrm{M}$ urea was neither the $41-\mathrm{kD}$ flagellar protein nor the P39 antigen described by Simpson and co-workers (36). Monoclonal antibodies directed against the $41-\mathrm{kD}$ flagellar and the P39 proteins reacted with their respective antigens in $B$. burgdorferi 297 but did not react with any component of the 6 $M$ urea eluant (Fig. 8). In addition, monospecific polyclonal antisera directed against $\mathrm{P} 39$ did not react with any component of the $6 \mathrm{M}$ urea eluant (data not shown).

\section{Discussion}

Attachment of microorganisms to cells of the host is believed to be a critical early step in microbial pathogenesis (5). The studies reported in this paper have identified and partially characterized a mechanism for borrelial cytoadhesion.

Previous in vitro studies of $B$. burgdorferi attachment have concentrated on the interaction of the spirochete with endothelial cells $(7,10,11)$. Epithelial cells, however, were used in the attachment and attachment-inhibition studies reported in this paper because heparin, generally in a concentration of $100 \mu \mathrm{g} /$ $\mathrm{ml}$ or more $(11,44)$, is used as a growth supplement in endothelial cell culture. In fact, heparin was such a potent inhibitor of borrelial attachment that the $\mathrm{ID}_{50}$ is at least 300 -fold less than the concentration routinely used in endothelial cell culture (7, 11 ). It is predicted, however, that results obtained in these studies will be expandable to other cell types including endothelial cells because of the ubiquitous distribution of surface-exposed PGs in mammalian systems $(17,45)$.

A reproducible HeLa cell-based binding assay was devel-

terial derived from intrinsically radiolabeled organisms. The 39-kD protein eluted by $6 \mathrm{M}$ urea (4), and the $40-(\bullet)$ and $38-\mathrm{kD}\left({ }^{*}\right)$ proteins eluted by $1 \mathrm{M} \mathrm{NaCl}$ are marked. Molecular mass markers in $\mathrm{kD}$ are shown on the left of each panel. $(A)$ Silver-stained gel of fractionation of detergent extract from unlabeled virulent $B$. burgdorferi strain 297. (B) Autoradiogram of fractionation of detergent extract from intrinsically labeled virulent $B$. burgdorferi strain 297. ( $C$ ) Silver-stained gel of fractionation of detergent extract from unlabeled avirulent $B$. burgdorferi strain B31. Lane $S, 0.02 \%$ Triton X-100 extract initially loaded onto column; lane $1,0.25 \mathrm{M} \mathrm{NaCl}-0.5 \%$ Triton $\mathrm{X}-100$ eluant; lane $2,0.5 \mathrm{M} \mathrm{NaCl}-0.5 \%$ Triton X-100 eluant; lane $3,1 \mathrm{M} \mathrm{NaCl}-0.5 \%$ Triton X-100 eluant; lane 4, $2 \mathrm{M} \mathrm{NaCl}-0.5 \%$ Triton $\mathrm{X}-100$ eluant; lane 5, $6 \mathrm{M}$ urea eluant. 
oped. As has been demonstrated in endothelial and glial cell studies $(7,11,46), B$. burgdorferi attached to HeLa cells in a dose-, time-, and temperature-dependent fashion. Borrelia also attached to monolayers pretreated with glutaraldehyde to prevent intracellular penetration. The inability to saturate attachment to both unfixed and fixed monolayers even at $B$. burgdorferi: HeLa cell ratios of $30,000: 1$ probably is due to spirochetespirochete binding at high concentrations of organisms. In general, the results obtained in the standard binding assay are comparable with those reported by other investigators, although the proportion of virulent $B$. burgdorferi HB19 which were attached/invasive after $4 \mathrm{~h}$ of co-incubation with the HeLa cell monolayer $(17 \pm 6 \%)$ is slightly greater than that reported by Thomas and Comstock under similar conditions $(3.6 \%)(11)$.

Although heparin was the most potent in vitro inhibitor of borrelial attachment, HS is the GAG of this class which is cell surface-associated and nearly all adherent mammalian cells express HS PGs $(13,14,47)$. A number of lines of experimental evidence support the hypothesis that $B$. burgdorferi attach to eukaryotic cell surface exposed PGs, including HS PGs. First, attachment-inhibition assays demonstrated that heparin, HS, and DS reduced virulent $B$. burgdorferi 297 attachment to HeLa cells in a dose-dependent manner. Although absolute borrelial attachment varied from experiment to experiment, both the maximal percentage attachment-inhibition and the $\mathrm{ID}_{50}$ were reproducible. GAG-mediated attachment-inhibition was not a technical artifact due to washing the organisms in PBS. Furthermore spirochetal motility, a surrogate marker for spirochetal viability, was maintained after incubation in heparin indicating that the attachment-inhibition was not due to a direct toxic effect of the GAG on the spirochete. Second, borrelial attachment to two mutant $\mathrm{CHO}$ cell lines deficient in HS PGs was reduced. As these mutant $\mathrm{CHO}$ cells were derived by chemical mutagenesis (37), the fact that consistent results were obtained from the two cell lines makes it is unlikely that additional uncharacterized mutations in either cell line were responsible for the observed decrease in borrelial attachment. Third, $B$. burgdorferi attachment was reduced by a similar degree to HeLa cell monolayers pretreated with heparinase and heparitinase and combined treatment with both lyases was not additive. This suggests that the borrelia are interacting with the heparin-like structures in the HS PGs. Furthermore, chondroitinase $\mathrm{ABC}$ but not chondroitinase $\mathrm{AC}$ reduced borrelial attachment suggesting that CS B may act as a target for the borrelial GAG receptor.

The promiscuous GAG receptor demonstrated by equilibrium binding studies has been putatively assigned a surface-exposed outer membrane location because the equilibrium binding studies and the in vitro attachment-inhibition studies were undertaken using intact organisms. Based on published experience with Treponema pallidum and B. burgdorferi $(35,42)$, low detergent concentrations were used to obtain detergent extracts which were enriched for $B$. burgdorferi outer membrane proteins. From such detergent extracts derived from virulent $B$. burgdorferi, a 39-kD borrelial molecule has been purified in microgram amounts by heparin affinity chromatography. It has such a high affinity for heparin that it is resistant to elution by $2 \mathrm{M} \mathrm{NaCl}$ and requires $6 \mathrm{M}$ urea to be eluted from the column. Furthermore, this protein is not purified when detergent extracts from avirulent $B$. burgdorferi $\mathrm{B} 31$ are applied to the affinity matrix. These combined data indicate that this 39 -
$\mathrm{kD}$ protein is a strong candidate for the $B$. burgdorferi $\mathrm{GAG}$ receptor. The low yield from this purification procedure is consistent with the low copy number of the $B$. burgdorferi GAG receptor predicted by Scatchard analysis. The subcellular location of the $39-\mathrm{kD}$ protein, however, is unknown because the detergent extracts contain cytoplasmic in addition to outer membrane proteins.

On the basis of immunoblotting studies, the $39-\mathrm{kD}$ protein is not one of the previously characterized borrelial antigens with similar molecular mass; i.e., it is neither the P39 nor the flagellar protein. Furthermore, the GAG receptor demonstrated by equilibrium binding studies cannot be the P39 antigen because the P39 antigen is present in avirulent B31 (36). Although OspA and OspB were present in trace amounts in the $1 \mathrm{M} \mathrm{NaCl}$ fractions, there are several lines of evidence which indicate that they are not the B. burgdorferi GAG receptor. First, avirulent $B$. burgdorferi B31 contains normal amounts of OspA and OspB but exhibits neither heparin attachment-inhibition to HeLa cells nor the GAG receptor. Second, Scatchard analyses indicate that the GAG receptor is present in much lower copy number than the highly abundant OspA and OspB. Third, OspA and OspB were eluted primarily in $0.25 \mathrm{M} \mathrm{NaCl}$ which strongly suggests that they are binding to heparin in a nonspecific manner.

The promiscuous nature of the B. burgdorferi GAG receptor with its variable affinity for different GAGs is consistent with other GAG binding receptors $(13,14,47)$. Although GAG-specific ligand-receptor interactions have been reported (14), most GAG receptors are able to bind to several GAGs with differing affinities $(13,14,47)$. Despite the structural heterogeneity of GAGs, GAG-receptor interactions are predominantly ionic in nature with charge density of the GAG being a major factor $(13,14)$. In general, this means that the most sulfated GAGs (e.g., heparin) have the highest affinity (14) and that the synthetic, highly charged, polyanionic dextran sulfates also interact with these receptors (48). The structure of the polysaccharide, however, is also important (48). For example, in previous studies $(13,14,47)$ and in experiments reported here (Fig. 2, Table II), HS and DS showed superior binding capacity compared to $\mathrm{CS}$, although each has a similar charge density; it has been speculated that iduronic acid in HS and DS confers conformational flexibility and allows enhanced interaction with the ligand (47).

The fact that GAGs inhibit $B$. burgdorferi attachment by a maximum of $\sim 60 \%$ indicates that $B$. burgdorferi, like other microbes (5), has several attachment mechanisms. The combined data, however, strongly support the hypothesis that one mode of $B$. burgdorferi attachment to host cells is mediated via a borrelial GAG binding receptor and host cell, surface-exposed PGs. Although $B$. burgdorferi utilizes a similar GAGmediated attachment mechanism to that employed by $T$. cruzi (25), the nature of the individual components of attachment process are different. $T$. cruzi has a GAG binding receptor which has greatest affinity for HS and heparin completely inhibits trypanosomal cytoadhesion (25); in contrast, $B$. burgdorferi has a promiscuous GAG receptor with greatest affinity for heparin and heparin only reduces attachment by $\sim 60 \%$. By extending the described spectrum of GAG-mediated microbial attachment mechanisms (17-20, 22, 25), these data support the notion that such mechanisms are a frequent theme of microbial attachment.

The observations with respect to virulent and avirulent $B$. 
burgdorferi strains extend previous studies $(7,11)$ and suggests that GAG-mediated attachment may be associated with virulence. All four virulent strains bound to HeLa cells in a similar manner and their attachment was heparin-inhibitable. Three of the avirulent strains attached poorly to the HeLa cells and did not demonstrate heparin-inhibitable attachment. Interestingly, the only avirulent strain which did demonstrate heparininhibitable attachment also attached to HeLa cells at a similar level as the parental virulent strain. Furthermore, avirulent $B$. burgdorferi B31 did not exhibit the moderately high-affinity GAG receptor which is demonstrated in virulent $\mathrm{B} 31$. The fact that one avirulent strain still demonstrates heparin attachment-inhibition does not exclude a role for GAG-mediated attachment in borrelial virulence. B. burgdorferi probably has multiple virulence determinants and loss of any one determinant may result in loss of virulence. The avirulent strains are obtained by prolonged in vitro culture and it seems unlikely that each strain will lose the same virulence factors in the same order each time they are passaged continuously in vitro. Further studies are required to establish definitively whether GAG-mediated attachment is a true virulence determinant.

These studies identify and partially characterize a borrelial cytoadhesion mechanism and extend previous studies which correlated cytoadhesion with $B$. burgdorferi virulence. Further delineation of the putative borrelial GAG receptor is warranted as it will increase our understanding of the pathogenesis of Lyme borreliosis.

\section{Acknowledgments}

I thank Drs. J. D. Radolf and S. Norris for providing strains of $B$. burgdorferi, Dr. J. Esko for providing CHO cell lines, Drs. M. V. Norgard and T. G. Schwan for providing antibody reagents, and S. Rao for technical assistance.

This work was supported by funds from the National Institutes of Health (BRSG) and from the Department of Veterans Affairs Research Service.

\section{References}

1. Burgdorfer, W., A. G. Barbour, S. F. Hayes, J. L. Benach, E. Grunwaldt, and J. P. Davis. 1982. Lyme disease-a tick-borne spirochetosis. Science (Wash. DC). 216:1317-1319.

2. Rahn, D. W., and S. E. Malawista. 1991. Lyme disease: recommendations for diagnosis and treatment. Ann. Intern. Med. 114:472-481.

3. Burgdorfer, W. 1991. Lyme borreliosis: ten years after the discovery of the etiologic agent, Borrelia burgdorferi. Infection. 19:257-262.

4. Rahn, D. W. 1991. Lyme disease: clinical manifestations, diagnosis, and treatment. Semin. Arthritis Rheum. 20:201-218.

5. Finlay, B. B., and S. Falkow. 1989. Common themes in microbial pathogenicity. Microbiol. Rev. 53:210-230.

6. Falkow, S. 1991. Bacterial entry into eukaryotic cells. Cell. 65:1099-1102.

7. Szczepanski, A., M. B. Furie, J. L. Benach, B. P. Lane, and H. B. Fleit. 1990. Interaction between Borrelia burgdorferi and endothelium in vitro. J. Clin. Invest. 85:1637-1647.

8. Hechemy, K. E., W. A. Samsonoff, H. L. Harris, and M. McKee. 1992. Adherence and entry of Borrelia burgdorferi in Vero cells. J. Med. Microbiol. 36:229-238.

9. Hechemy, K. E., W. A. Samsonoff, M. McKee, and J. M. Guttman. 1989. Borrelia burgdorferi attachment to mammalian cells. J. Infect. Dis. 159:805-806.

10. Ma, Y., A. Sturrock, and J. J. Weis. 1991. Intracellular localization of Borrelia burgdorferi within human endothelial cells. Infect. Immun. 59:671-678.

11. Thomas, D. D., and L. E. Comstock. 1989. Interaction of Lyme disease spirochetes with cultured eucaryotic cells. Infect. Immun. 57:1324-1326.

12. Szczepanski, A., and J. L. Benach. 1991. Lyme borreliosis: host responses to Borrelia burgdorferi. Microbiol. Rev. 55:21-34.

13. Jackson, R. L., S. J. Busch, and A. D. Cardin. 1991. Glycosaminoglycans: molecular properties, protein interactions, and role in physiological processes. Physiol. Rev. 71:481-539.

14. Ruoslahti, E. 1988. Structure and biology of proteoglycans. Annu. Rev. Cell Biol. 4:229-255.

15. Iozzo, R. V. 1985. Proteoglycans: structure, function, and role in neoplasia. Lab. Invest. 53:373-396.

16. WuDunn, D., and P. G. Spear. 1989. Initial interaction of herpes simplex virus with cells is binding to heparan sulfate. J. Virol. 63:52-58.

17. Shieh, M.-T., D. WuDunn, R. I. Montgomery, J. D. Esko, and P. G. Spear. 1992. Cell surface receptors for herpes simplex virus are heparan sulfate proteoglycans. J. Cell Biol. 116:1273-1281.

18. Okazaki, K., T. Matsuzaki, Y. Sugahara, J. Okada, M. Hasebe, Y. Iwamura, M. Ohnishi, T. Kanno, M. Shimizu, E. Honda, and Y. Kono. 1991. BHV1 adsorption is mediated by the interaction of glycoprotein gIII with a heparinlike moiety on the cell surface. Virology. 181:666-670.

19. Mettenleiter, T. C., L. Zsak, F. Zuckermann, N. Sugg, H. Kern, and T. Ben-Porat. 1990. Interaction of glycoprotein gIII with a cellular heparin-like substance mediates adsorption of pseudorabies virus. J. Virol. 64:278-286.

20. Zhang, J. P., and R. S. Stephens. 1992. Mechanism of C. trachomatis attachment to eukaryotic host cells. Cell. 69:861-869.

21. Menozzi, F. D., C. Gantiez, and C. Locht. 1991. Interaction of Bordetella pertussis filamentous hemagluttinin with heparin. FEMS Microbiol. Lett. 78:5964.

22. Butcher, B. A., L. A. Sklar, L. C. Seamer, and R. H. Glew. 1992. Heparin enhances the interaction of infective Leishmania donovani promastigotes with mouse peritoneal macrophages: a fluorescence flow cytometric analysis. $\mathrm{J}$. Immunol. 148:2879-2886.

23. Mukhopadhyay, N. K., K. Shome, A. K. Saha, J. R. Hassell, and R. H. Glew. 1989. Heparin binds to Leishmania donovani promastigotes and inhibits protein phosphorylation. Biochem. J. 264:517-525.

24. Butcher, B. A., K. Shome, L. W. Estes, J. Choay, M. Petitou, P. Sie, and R. H. Glew. 1990. Leishmania donovani: cell-surface heparin receptors of promastigotes are recruited from an internal pool after trypsinization. Exp. Parasitol. 71:49-59.

25. Ortega-Barria, E., and M. E. A. Pereira. 1991. A novel T. cruzi heparinbinding protein promotes fibroblast adhesion and penetration of engineered bacteria and trypanosomes into mammalian cells. Cell. 67:411-421.

26. Barbour, A. G. 1984. Isolation and cultivation of Lyme disease spirochetes. Yale J. Biol. Med. 57:521-525.

27. Moody, K. D., S. W. Barthold, and G. A. Terwilliger. 1990. Lyme borreliosis in laboratory animals: effect of host species and in vitro passage of Borrelia burgdorferi. Am. J. Trop. Med. Hyg. 43:87-92.

28. Schwan, T. G., W. Burgdorfer, and C. F. Garon. 1988. Changes in the infectivity and plasmid profile of the Lyme disease spirochete, Borrelia burgdorferi, as a result of in vitro cultivation. Infect. Immun. 56:1831-1836.

29. Barthold, S. W., D. H. Persing, A. L. Armstrong, and R. A. Peeples. 1991. Kinetics of Borrelia burgdorferi dissemination and evolution of disease after intradermal inoculation of mice. Am. J. Pathol. 139:263-273.

30. Schenkman, S., C. Diaz, and V. Nussenzweig. 1991. Attachment of Trypanosoma cruzi trypomastigotes to receptors at restricted cell surface domains. Exp. Parasitol. 72:76-86.

31. Liang, O. D., F. Ascencio, L.-A. Fransson, and T. Wadstrom. 1992. Binding of heparan sulfate to Staphylococcus aureus. Infect. Immun. 60:899-906.

32. Munson, P. J., and D. Rodbard. 1980. LIGAND: a versatile computerized approach for characterization of ligand-binding systems. Anal. Biochem. 107:220-239.

33. Scatchard, G. 1949. The attraction of proteins for small molecules and ions. Ann. N.Y. Acad. Sci. 51:660-672.

34. Laemmli, U. K. 1970. Cleavage of structural proteins during the assembly of the head of bacteriophage T4. Nature (Lond.). 227:680-685.

35. Radolf, J. D., N. R. Chamberlain, A. Clausell, and M. V. Norgard. 1988. Identification and localization of integral membrane proteins of virulent Treponema pallidum subsp. pallidum by phase partitioning with the nonionic detergent Triton X-114. Infect. Immun. 56:490-498.

36. Simpson, W. J., M. E. Schrumpf, and T. G. Schwan. 1990. Reactivity of human Lyme borreliosis sera with a 39-kilodalton antigen specific to Borrelia burgdorferi. J. Clin. Microbiol. 28:1329-1337.

37. Esko, J. D., T. E. Stewart, and W. H. Taylor. 1985. Animal cell mutants defective in glycosaminoglycan biosynthesis. Proc. Natl. Acad. Sci. USA. 82:3197-3201.

38. Esko, J. D., K. S. Rostand, and J. L. Weinke. 1988. Tumor formation dependent on proteoglycan biosynthesis. Science (Wash. DC). 241:1092-1096.

39. Bame, K. J., and J. D. Esko. 1989. Undersulfated heparan sulfate in a Chinese hamster ovary cell mutant defective in heparan sulfate $\mathrm{N}$-sulfotransferase. J. Biol. Chem. 264:8059-8065.

40. Bame, K. J., K. Lidholt, U. Lindah, and J. D. Esko. 1991. Biosynthesis of heparan sulfate. Coordination of polymer-modification reactions in a Chinese hamster ovary cell mutant defective in N-sulfotransferase. J. Biol. Chem. 266:10287-10293. 
41. Nader, H., C. P. Dietrich, V. Buonassisi, and P. Colburn. 1987. Heparin sequences in the heparan sulfate chains of an endothelial cell proteoglycan. Proc. Natl. Acad. Sci. USA. 84:3565-3569.

42. Brusca, J. S., A. W. McDowall, M. V. Norgard, and J. D. Radolf. 1991 Localization of outer surface proteins $A$ and $B$ in both the outer membrane and intracellular compartments of Borrelia burgdorferi. J. Bacteriol. 173:8004-8008.

43. Neugebauer, J. M. 1990. Detergents: an overview. Methods Enzymol. 182:239-253.

44. Riley, B. S., N. Oppenheimer-Marks, E. J. Hansen, J. D. Radolf, and M. V. Norgard. 1992. Virulent Treponema pallidum activates human vascular endothelial cells. J. Infect. Dis. 165:484-493.

45. Wight, T. N., M. G. Kinsella, M. W. Lark, and S. Potter-Perigo. 1986 Vascular cell proteoglycans: evidence for metabolic modulation. Ciba Found. Symp. 124:241-259.
46. Garcia-Monco, J. C., B. Fernandez-Villar, and J. L. Benach. 1989. Adherence of the Lyme disease spirochete to glial cells and cells of glial origin. J. Infect. Dis. 160:497-506.

47. Kjellen, L., and U. Lindahl. 1991. Proteoglycans: structures and interactions. Annu. Rev. Biochem. 60:443-475.

48. Ruoslahti, E., A. Pekkala, and E. Engvall. 1979. Effect of dextran sulfate on fibronectin-collagen interaction. FEBS Lett. 107:51-54.

49. Steere, A. C., R. L. Grodzicki, A. N. Kornblatt, J. E. Craft, A. G. Barbour, W. Burgdorfer, G. P. Schmid, E. Johnson, and S. E. Malawista. 1983. The spirochetal etiology of Lyme disease. $N$. Engl. J. Med. 308:733-740.

50. Georgilis, K., A. C. Steere, and M. S. Klempner. 1991. Infectivity of Borrelia burgdorferi correlates with resistance to elimination by phagocytic cells. J. Infect. Dis. 163:150-155. 